\title{
F-18 Sodium Fluoride Positron Emission Tomography
}

National Cancer Institute

\section{Source}

National Cancer Institute. F-18 Sodium Fluoride Positron Emission Tomography. NCI

Thesaurus. Code C93202.

Computed tomography that uses F[18] as a positron source for 3-dimensional imaging. 